\title{
Validation of the Smart City as a Sustainable Development Knowledge Tool: The Challenge of Using Technologies in Education during COVID-19
}

\author{
María del Carmen Olmos-Gómez ${ }^{1, * \mathbb{C}}$, Mónica Luque-Suárez ${ }^{2, *}$, Soraya Mohamed-Mohamed ${ }^{1}$ \\ and Jesús Manuel Cuevas-Rincón ${ }^{1}$ \\ 1 Department of Research Methods and Diagnosis in Education, Faculty of Education and Sport Science, \\ University of Granada, 52005 Melilla, Spain; sorayasori@correo.ugr.es (S.M.-M.); jcuevas@ugr.es (J.M.C.-R.) \\ 2 Department of Sociology, Faculty of Education and Sport Science, University of Granada, \\ 52005 Melilla, Spain \\ * Correspondence: mcolmos@ugr.es (M.d.C.O.-G.); mlsuarez@ugr.es (M.L.-S.)
}

Received: 2 September 2020; Accepted: 5 October 2020; Published: 12 October 2020

\begin{abstract}
The objective of this research was to design and validate a questionnaire for teachers on the knowledge and use of smart city concepts and their usefulness in online learning during the COVID-19 pandemic based on a sustainable approach at different educational levels. It is important to analyze the use of online education based on the construction of intelligent learning environments, which favor the interaction between the environment and the student. With a quasi-experimental methodology, the psychometric properties of the questionnaire were analyzed through structural equation modeling (SEM), and the model was adjusted through a multivariate regression analysis to relate response patterns to a set of latent factors that cannot be directly observed, but exist in continuous dimensions of the people evaluated, and to create a valid and reliable instrument as a measurement tool using a sample of $n=973$ subjects. The sample distribution consisted of $22.36 \%$ primary school teachers, $59.01 \%$ high school teachers, and $18.56 \%$ university teachers. The results showed a high reliability and construct validity through two models, and adjustment of the original model produced better goodness-of-fit parameters. We conclude that the designed questionnaire is a useful and valid tool for understanding how teachers have approached online teaching during the pandemic and their knowledge and use of Smart City concepts.
\end{abstract}

Keywords: Smart Cities; ICT; structural equation modeling (SEM); readjustment; e-learning

\section{Introduction}

Cities are constantly changing, and if we take into account the pandemic caused by the SARS-CoV-2 virus (COVID-19) [1-3] that is spreading worldwide, the pace of change is even faster. As a result of this new reality, information and communication technologies (ICTs) are gaining momentum, and the concept of the Smart City is beginning to be heard more and more frequently $[4,5]$. This is the central focus of our research, which was carried out during a health crisis that has led the governments of almost all countries to order lockdowns of cities and schools [6,7] to prevent the spread of the infection, with significant implications for the world of education.

Today's society is very sensitive to environmental problems generated by humans [8]. According to previous studies [9], the population is not educated in current issues related to sustainable development. However, scientifically competent citizens and professionals are needed to address environmental threats to sustainability. With the aim of addressing this need, social networks are becoming an increasingly popular area of research, and recent studies and literature have shown that the media is 
an effective tool to facilitate learning about sustainable development (SD) [10-17]. At first, the term Smart City focused on the relevance of ICTs for the achievement of a more competitive status and a more sustainable development [18]. When reviewing the literature on the concept of the Smart City, we encounter considerable controversy [19-24]. There are authors who associate this term with the cultural and professional growth of the members of a society who live in the same environment [25], while other authors associate it with the impact of ICTs and the expansion of their infrastructure [26]. The central definition used in our research, though, would be based on the consideration of Smart Cities in relation to ICTs and the opportunities that they provide for the benefit of citizens [27]. Therefore, the impact of the Smart City in education is important, since it saves costs in its management by using technological advances [28].

In essence, the idea of Smart Cities, according to the European Parliament [29], is based on the creation and connection of human capital, social capital, and infrastructure of information and communication technologies (ICTs) to promote a sustainable economic development and a better quality of life, understanding that Smart Cities comprise six areas: smart governance, smart people, smart living, smart mobility, smart economy, and smart environment. In Figure 1, we can observe how the information systems of Smart Cities will help improve infrastructures and develop a communication system that operates throughout such cities, providing an information and knowledge network in response to the services available. Thus, this convergence between ICTs and Smart Cities will, in turn, promote new ecosystems within the latter [30].

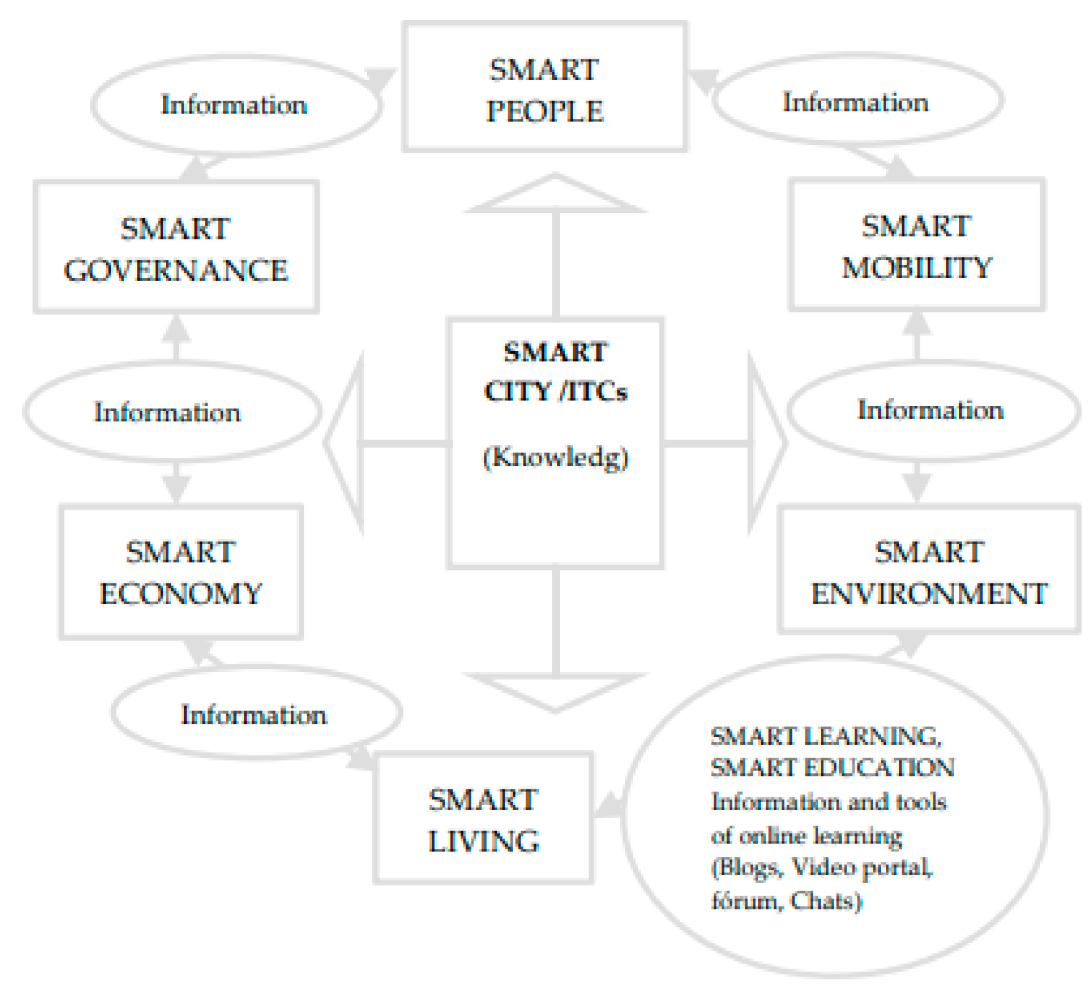

Figure 1. Developed from mapping of Smart Cities in the EU.

In this research study, we focused on Smart Cities as platforms that allow maximization of the economy, environment, and well-being of citizens, and they also facilitate the transformation of the cities mentioned above towards a more sustainable behavior [31,32]. In order to do so, education authorities are responsible for developing online portals and web-based applications to deliver lectures or other teaching activities as a means of ensuring that education continues for the remainder of the academic year [33]. In order to achieve such a citizenry, it is necessary to enhance their education through the 
use of alternative learning strategies, that is, by making use of technology such as ubiquitous learning, understood as "the possibility of accessing information anywhere or anytime" [34], cooperative learning [35], exploratory learning outside the classroom [36], and game-based learning [37]. Faced with this pandemic scenario, public administrations have to consider an evolution in city management models. For this, the use of ICTs is essential, and this translates into the Smart City concept, which, with its services, advances what is called the Internet of Things (IoT), that is, the Internet of the future $[38,39]$. Nowadays, with the growing popularity of multimedia and mobile devices, the IoT is becoming a reality, and mobile technology is beginning to enable new forms of learning environments that can be useful for students in different educational contexts, as well as for teachers $[40,41]$. Nowadays, the concept of Smart is used in educational research, giving rise to new concepts such as Smart Learning Environments, Smart Learning, Smart Education, Smart Classrooms, and Smart Universities [42].

This COVID-19 situation has marked a turning point in the way of facing learning as well as in the way of teaching. Therefore, health authorities should consider providing online psychoeducation [43], focusing on the level of know-how with regard to information and communication technologies (ICTs), attitudes, and planned future uses, as well as the actual ICTs used by teachers and teenagers in the knowledge society [44-46].

In addition, we must bear in mind that these virtual environments favor and promote social interaction, since they provide a collaborative learning framework between teachers and students [47]. Virtual classroom formats that can be used for comprehensive education include videos, forums, video calls, and photos. These technologies are characterized by the ability to save and broadcast a lesson in an electronic format [48].

It is precisely based on this approach that the use of mobile technologies plays a key role in teaching, although the vulnerability of these devices to privacy threats and data exploitation as a result of cyberattacks must be taken into account [49].

Therefore, as the educational potential of mobile social networks increases [50], their educational possibilities should be explored [51].

As a result of the COVID-19 pandemic, which is an unprecedented situation for all sectors of society and for education in particular (the subject addressed in this study), face-to-face classes have been urgently adapted to a remote format. In other words, what was first proposed as a replacement for teaching activities has led to non-face-to-face evaluation scenarios [52,53], which have encouraged a wider use of mobile technologies and the Internet.

We are currently immersed in a knowledge society, characterized by information and communication technologies (ICTs) and globalization, which is based on knowledge rather than on the search for and collection of information [54]. In our society, technological advances are continuous and constant, which has created a "digital culture" [55]. Some teachers may have experienced apprehension when transitioning to online classes, but most of them have done so at a rapid pace and in a short period of time; in the long run, they all seem to be adjusting well, although the digital gap is more evident than ever [56].

Based on the considerations stated above, and as a novel contribution, this research aimed to:

(1) Design and validate an instrument in order to analyze the impact of an online learning questionnaire, a Smart City tool, on teaching during a lockdown. This is important because no instrument currently exists to examine these parameters. A questionnaire was designed and validated in compliance with the established psychometric requisites for reliability. In order to confirm these characteristics, structural equation modeling (SEM) was used. This methodology enables latent analysis, which is consistent with the use of multivariate regression to relate patterns of answers to a group of factors that are not directly observed but exist in the people assessed [57].

(2) Obtain descriptive results for use of the Smart City tool of online learning in teaching during a lockdown. 


\section{Materials and Methods}

\subsection{Method}

Since the aim was to use a questionnaire to determine the acquired knowledge that exists with respect to ICT applications [58], how they are used by teachers, and the general use of links for accessing information on learning in a Smart City, this research used a quantitative methodology. The questionnaire was tested for its rigor, adaptability to context, validity, reliability, and its capacity to offer objective data with respect to the studied phenomenon.

The two psychometric properties that should be demanded of any measurement tool are reliability and validity, which are both essential for making inferences from the relevant data and making decisions accordingly. A tool is considered trustworthy when various measurements of the same attribute or characteristic are internally coherent. The more stable the measurements of an attribute, the greater the reliability of the tool over repeated measurements. Mathematically, reliability is defined as the proportion of the true variance in the test results.

This research used the questionnaire as a tool to collect data on opinions or information among teachers of education during COVID-19 on the use of the Smart City tool of an online learning questionnaire [58-60]. The aim was to establish theoretical processes, metrics, and validity to maximize the inferences that could be made from the questionnaire's use. However, the scores of questionnaires, from a methodological and statistical point of view, may contain errors arising from multiple sources, which have to be minimized through various procedures [61]. To minimize such possible errors, a type of inferential analysis was performed that uses multivariate regression to relate response patterns to a set of latent factors that are not directly observed, but are detected in accordance with the substantive theory [57]; that is, an analysis based on the structural equation modeling (SEM) within a factor analysis was carried out. These analyses allowed us to test the constructed model to establish a hypothesis on the structure of the construct [62]. In addition, with the readjustment of the SEM model, some procedures and technical criteria were provided for the validation of model measurements [63] to establish that a conditional independence exists, understood as a set of mutually independent latent factors quantified by means of a dimensional structure based on substantive theory, which postulates the presence of a causal effect in the answers of the sample.

The modeling of structural equations is a type of inferential analysis in which multivariate regression is used in order to relate response patterns to a set of latent factors that cannot be directly observed, but exist in continuous dimensions of the people evaluated. It also provides the most robust technical procedures and criteria for the validation of a questionnaire, specifying the latent features and the dimensions that represent them as variables of interest (factors) and relating the validated evidence with the dimensional structure of the instrument under evaluation through goodness-of-fit criteria and indices, which are complemented by a re-specification of the measurement model in order to improve the fit of the model by adding or eliminating relationships between the factors, all based on the analysis of the covariance structures of the observed variables and those reproduced by the model [63].

The first phase begins with the design of the questionnaire, and ends with the analysis of the information that it provides. In this analysis, the structure of the relationship between the latent variables represented by the dimensions of the instrument (knowledge of computer programs, use of ICTs, impact that ICTs have on the teaching process, learning style, the concept of smart cities, and knowledge and use of video and audio editing programs) and the responses to the items of the context questionnaire was established. In this model, the latent factors are the dimensions (factors) proposed in Figure 2, and the observed variables are the values obtained from the responses to the items of the questionnaire. 


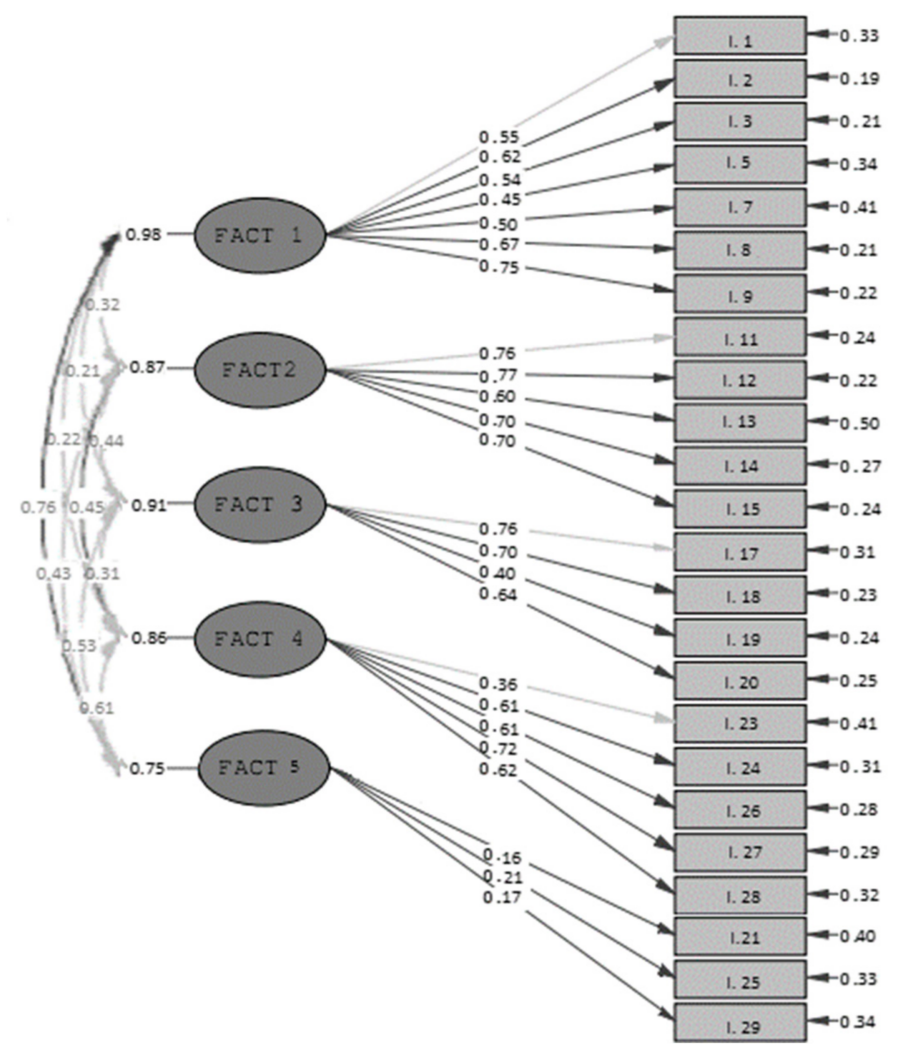

Figure 2. Schematic (path graph) of the Questionnaire on the Knowledge and Use of the Smart City and Its Usefulness in Online Learning (SCOLQ). Model 1 (M1).

The second confirmatory phase involves analyzing the covariance structure in the database containing the 24 observed variables and trying to obtain evidence of validity to confirm that the measurement model coincides with the conceptual structure postulated in the dimensionality theory (factors were reduced from 6 to 5 to achieve a better goodness of fit) of the questionnaire when comparing two covariance structures. The first one is referred to as the covariance matrix of the observed variables (five factors). The second is known as the covariance matrix implied by the model (24 items). This distinction is observed in the graphical representation of the theoretical-conceptual structure of the instrument shown in Figure 2. We observed the weights of the coefficients and their relationship, finding out that when the latent variable increases, the observed variable increases too, according to the weight of the coefficient [63]. Finally, the re-specification of the model confirms the structure of four factors and 21 items as the final validation result, since the fit indices are more appropriate (Figure 3).

According to Zhu and He [64], smart education, or intelligent education, is based on the construction of intelligent learning environments through the use of intelligent technology, making it possible to use intelligent pedagogies that offer individualized learning. This requires sharp thinking, considerable behavioral competence, and appropriate orientation; thus, the first dimension of our questionnaire was based on knowledge of computer programs and their use in the practice of teaching. All items linked to the knowledge and use of basic programs, blogs, etc. were integrated in this dimension.

A smart learning environment favors the interaction between the environment and the student. Such learning cannot take place without the support of smart learning environments [65]. Middleton [66] pointed out that intelligent and personalized technologies encourage the participation of students in their own learning process, thus increasing autonomy in the aspects of connectedness and openness and resulting in more enriched personal environments. 


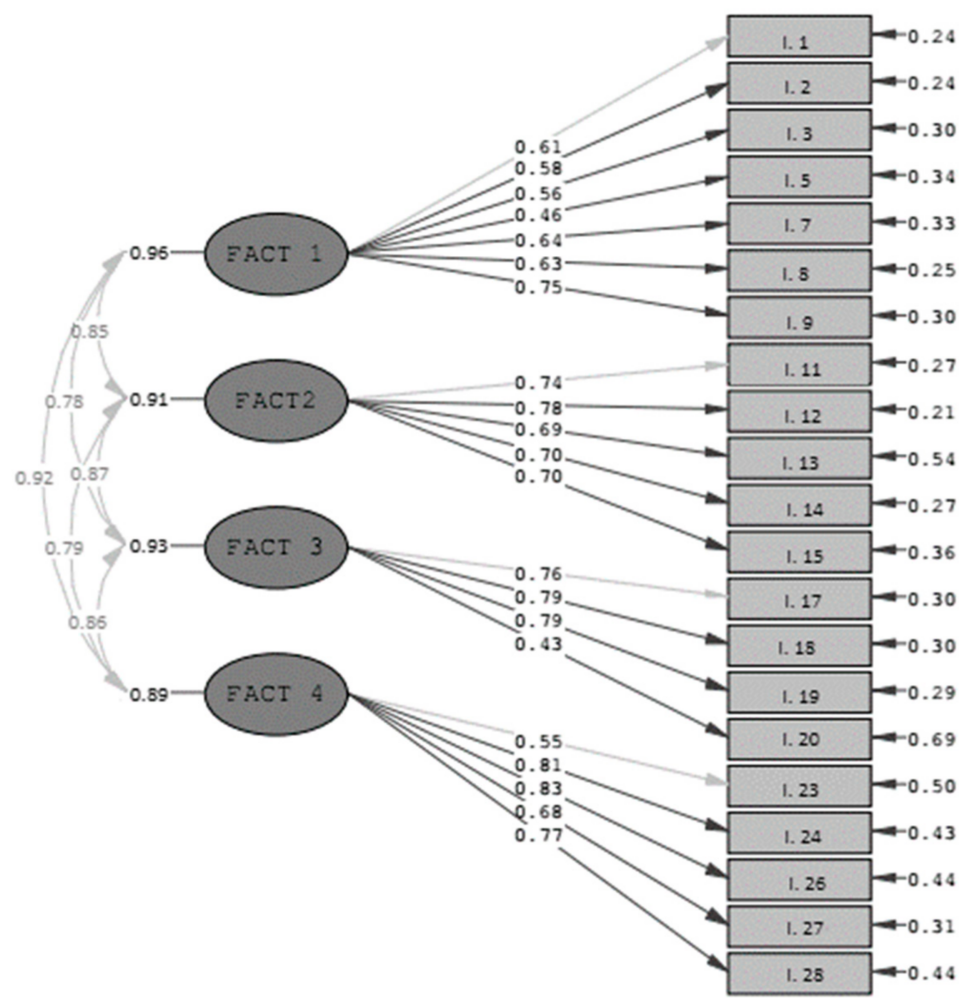

Figure 3. Schematic (path graph) of the Questionnaire on the Knowledge and Use of the Smart City and Its Usefulness in Online Learning (SCOLQ). Model 2 (M2).

In Liu, Hwang, and Wosinki's [67] study on a smart learning environment, each student had a smart mobile device. This device allowed for annotations and comments, bookmarking, and access to multimedia links. This arrangement is called an e-textbook. In addition to offering an enrichment of learning, the device provided information on the evolution of student learning; the data were stored in the cloud, student performance was analyzed, and the results were presented through statistics. We also designed a third dimension that focused on the impact of ICTs on the teaching process.

Intelligent learning requires the development an intelligent classroom that involves learning to encourage, collaborate, interact, and carry out self-directed learning through ICTs [68]. Today, the concept of "smart" is widely used in educational research, resulting in the creation of new concepts, such as the smart learning environment, smart learning, smart education, smart classroom, and smart university [69]. Its development is of vital importance in teaching. Thus, in the last section of the questionnaire, we developed items focused on the knowledge and use of Smart City tools as well as their usefulness in online learning.

Although it is possible that the results obtained via a questionnaire include a certain margin of error for various reasons, this is reduced when the psychometric parameters are rigorously defined.

This part of our research was based on a quantitative study using social/analytical/empirical research of a descriptive nature [70].

\subsection{Participants}

The sample participants were selected on a non-probabilistic basis. The study cohort was composed of teachers belonging to different educational cycles: primary, secondary, and university levels.

The non-probabilistic sampling (convenience) data comprised a total of $n=973$ teacher participants. The sample distribution consisted of $22.36 \%$ primary school teachers, $59.01 \%$ high school teachers, and $18.56 \%$ university teachers. With respect to the religion variable, $n=281(28.87 \%)$ were Muslim, 
$n=509(52.31 \%)$ were Catholic, $n=12(1.23 \%)$ were Jewish, $n=169(17.36 \%)$ were atheists, and $n=2$ $(0.20 \%)$ were Hindu.

The ages of participating teachers ranged between 28 and 63 years old (mean $=48.5$ years). A total of $n=381$ were male $(39.15 \%)$ and $n=592$ were female $(60.84 \%)$.

\subsection{Instrument}

Each participant completed a modified version of the questionnaire on the smart city tool of online learning [60], limited and adapted to the border context of the city of Melilla and modified for the variable of religion. To select the initial items to be included in the questionnaire, a group of students $(n=502)$ with largely similar characteristics to those of the sample respondents were asked to indicate all the items they considered to be best suited to the purposes of the research. After collecting this information, we proceeded to validate the items using an expert panel analysis via Delphi's method [71]. Six experts assessed the instrument. They indicated when an item was unclear or poorly worded and made comments on its relevance, congruence, and adequacy. The experts who participated as judges in the content validation process were professors with PhDs in the areas of research, evolutionary psychology, and social sciences, which guaranteed their expertise in this process [71,72]. The final version of the instrument was developed in the exploratory phase. For this purpose, three rounds of content validity analysis were carried out among the experts. The percentage of agreement was $78 \%$ in the first round of validation, $81 \%$ in the second round, and $91 \%$ in the third round.

The survey had two parts, with the first part devoted to sociodemographic information: age, gender, and religion. The second part included questions on the frequency of expressed opinions on the elements included in the questionnaire on a four-point Likert scale, where $1=$ "none" and $4=$ "a lot". An exploratory factor analysis (EFA) was applied to test the validity of the construct. Factor analysis of the variables was carried out to ensure the validity and reliability of the tool. Validity was measured using the calculated Kaiser-Meyer-Olkin index (KMO), the value of which must be over 0.5. In this case, the KMO was 0.900 , close to 1 , indicating that it was appropriate to continue analyzing the validity and reliability of the questionnaire. The Bartlett sphericity test was used to ensure that the significance was adequate $(p=0.000)$, allowing us to proceed to the factor analysis. A table of variance in a rotated component matrix provided the variance over all the variables studied. The results of the analysis highlighted five factors that explained the variance, with a total sum value of $68.051 \%$.

\subsection{Procedure}

\section{Data Collection Procedure}

The questionnaire was administered over the months of March and April in 2020 and was approved by the directors of the participating schools, who collaborated in the research and indicated the best periods for data collection. The cooperation and social responsibility department of the University of Granada approved the questionnaire. Before completing the questionnaire, participants were provided with the following statement: "Before answering the following questionnaire, it is essential that you provide us with your informed, unequivocal, and expressed consent regarding the privacy and data protection regulations, in accordance with the provisions of Regulation (EU) 2016/679, of 27 April 2016(GDPR)". Additionally, the ethical principles of the Declaration of Helsinki were followed at all times. The questionnaires were handed out to the students with a brief presentation and then read as a group to allow for any questions asking for clarification. Each questionnaire took approximately $25 \mathrm{~min}$ to fill out. Statistical analysis was carried out to establish construct validity and reliability of the questionnaire. We guaranteed that anonymity would be preserved throughout and that all information would be used for purely scientific research purposes.

The information collection instrument was composed of 29 items grouped into five sections. The first section consisted of data identifying the participants (sex, age, and educational stage). For 
the remaining four sections, a Likert scale was used. The scores were coded from 1 to 4 ( $1=$ "none"; $2=$ "some"; 3 = "quite a bit", and $4=$ "a lot"). Four values were chosen to avoid intermediate values.

\subsection{Data Analysis}

For the descriptive analysis and the exploratory factorial semi-confirmatory analysis of internal consistency, SPSS 24.0 (SPSS Statistics 24.0 Chicago, IL, USA, 2016) was used as the statistical program. For confirmatory factor analysis (CFA) of structural equation modeling (SEM), the statistical program LISREL v9.1 (Scientific Software International, Princeton, NJ, USA, 2010) was used.

\section{Results}

The descriptive results of the response percentages and their standard deviations were obtained for the different questions. The standard deviations of the items were higher than 0.63 , which reflected an appropriate discriminability. Likewise, the corrected item total correlation was positive for all items, which indicated a strong linear correlation, with values between 0.097 and 0.791 (Table 1).

Table 1. Descriptive results of the Questionnaire on the Knowledge and Use of the Smart City and Its Usefulness in Online Learning (SCOLQ).

\begin{tabular}{|c|c|c|c|c|c|c|c|}
\hline \multirow{2}{*}{ Item } & \multicolumn{4}{|c|}{ Percentage (\%) } & \multirow{2}{*}{$\bar{x}$} & \multirow[b]{2}{*}{ SD } & \multirow[b]{2}{*}{ RI-t } \\
\hline & 1 & 2 & 3 & 4 & & & \\
\hline 1 & 3.1 & 9.9 & 36 & 50.9 & 3.34 & 0.784 & 0.654 \\
\hline 2 & 1.9 & 11.2 & 32.9 & 54.04 & 3.39 & 0.759 & 0.504 \\
\hline 3 & 3.1 & 8.7 & 29.2 & 59.0 & 3.44 & 0.781 & 0.590 \\
\hline 4 & 9.3 & 39.8 & 26.1 & 24.8 & 2.66 & 0.954 & 0.575 \\
\hline 5 & 1.9 & 9.3 & 28.0 & 60.9 & 3.47 & 0.743 & 0.566 \\
\hline 6 & 73.9 & 19.9 & 5.0 & 1.2 & 1.33 & 0.631 & 0.228 \\
\hline 7 & 5.6 & 8.1 & 28.0 & 58.4 & 3.39 & 0.860 & 0.648 \\
\hline 8 & 3.1 & 11.2 & 32.3 & 53.4 & 3.36 & 0.802 & 0.550 \\
\hline 9 & 5.6 & 18.3 & 27.3 & 48.4 & 3.18 & 0.930 & 0.692 \\
\hline 10 & 22.4 & 29.8 & 25.5 & 22.4 & 2.47 & 1.07 & 0.575 \\
\hline 11 & 5.0 & 13.7 & 23.0 & 58.4 & 3.34 & 0.896 & 0.577 \\
\hline 12 & 17.4 & 23.0 & 34.2 & 25.5 & 2.67 & 1.040 & 0.654 \\
\hline 13 & 16.8 & 17.4 & 34.8 & 31.1 & 2.80 & 1.059 & 0.611 \\
\hline 14 & 5.0 & 13.0 & 31.7 & 50.3 & 3.27 & 0.873 & 0.643 \\
\hline 15 & 11.8 & 21.1 & 31.7 & 35.4 & 2.90 & 1.017 & 0.665 \\
\hline 16 & 6.2 & 11.8 & 30.4 & 51.6 & 3.27 & 0.901 & 0.791 \\
\hline 17 & 7.5 & 16.1 & 40.4 & 36.0 & 3.04 & 0.906 & 0.705 \\
\hline 18 & 17.4 & 26.1 & 35.4 & 21.1 & 2.60 & 1.007 & 0.562 \\
\hline 19 & 5.6 & 19.9 & 41.6 & 32.9 & 3.01 & 0.869 & 0.653 \\
\hline 20 & 7.5 & 19.3 & 37.3 & 36.0 & 3.01 & 0.925 & 0.617 \\
\hline 21 & 47.2 & 25.5 & 18.6 & 8.7 & 1.88 & 0.999 & 0.369 \\
\hline 22 & 13.0 & 19.9 & 45.3 & 21.7 & 2.75 & 0.940 & 0.733 \\
\hline 23 & 11.2 & 15.5 & 41.6 & 31.7 & 2.93 & 0.959 & 0.696 \\
\hline 24 & 8.7 & 10.7 & 30.4 & 50.3 & 3.22 & 0.955 & 0.672 \\
\hline 25 & 54.0 & 24.2 & 16.8 & 5.0 & 1.72 & 0.915 & 0.097 \\
\hline 26 & 16.1 & 32.9 & 36.0 & 14.9 & 2.49 & 0.936 & 0.384 \\
\hline 27 & 14.3 & 32.3 & 32.9 & 20.5 & 2.59 & 0.970 & 0.525 \\
\hline 28 & 11.2 & 25.5 & 47.8 & 15.5 & 2.67 & 0.870 & 0.593 \\
\hline 29 & 45.3 & 29.8 & 16.1 & 8.7 & 1.88 & 0.977 & 0.366 \\
\hline
\end{tabular}

Note: Percentage of the scale, mean, standard deviation, and corrected item total correlation. The scale values are $1=$ "none", 2 = "some", 3 = "quite a bit" and $4=$ "a lot"; $\mathrm{SD}=$ standard deviation. RI-t = corrected item total correlation.

With regard to the results obtained for the respondents in the sample for each of the items in the Questionnaire on the Knowledge and Use of the Smart City and Its Usefulness in Online Learning (SCOLQ), it was observed that teachers of education during the COVID-19 pandemic did not follow 
a normal distribution (Table 2). This was indicated by the indices of asymmetry, kurtosis, and the Kolmogorov-Smirnov test. All the items expressed negative asymmetry, which implies that the professionals tended to select high values on the Likert scale, except for the following items: 4, 5, 6, 10, 21,25 , and 29. These items showed positive asymmetry, which means that the participants tended to choose low values on the scale.

Table 2. Asymmetry, kurtosis, and Kolmogorov-Smirnov test results for the Questionnaire on the Knowledge and Use of the Smart City and Its Usefulness in Online Learning (SCOLQ).

\begin{tabular}{|c|c|c|c|c|}
\hline Items & Asymmetry & Kurtosis & $\mathbf{Z}$ & $p$ \\
\hline 1 & -1.095 & 0.715 & 3.887 & 0.000 \\
\hline 2 & -1.054 & 0.424 & 4.173 & 0.000 \\
\hline 3 & -1.354 & 1.276 & 4.478 & 0.000 \\
\hline 4 & 0.064 & -1.276 & 3.140 & 0.000 \\
\hline 5 & 1.317 & 1.097 & 4.664 & 0.000 \\
\hline 6 & 1.998 & 3.861 & 5.600 & 0.000 \\
\hline 7 & -1.389 & 1.177 & 4.369 & 0.000 \\
\hline 8 & -1.113 & 0.569 & 4.078 & 0.000 \\
\hline 9 & -0.806 & -0.462 & 3.726 & 0.000 \\
\hline 10 & 0.057 & -1.243 & 2.460 & 0.000 \\
\hline 11 & -1.168 & 0.294 & 4.447 & 0.000 \\
\hline 12 & -0.263 & -1.089 & 2.768 & 0.000 \\
\hline 13 & -0.455 & -1.003 & 2.954 & 0.000 \\
\hline 14 & -1.020 & 0.200 & 3.813 & 0.000 \\
\hline 15 & -0.496 & -0.903 & 2.699 & 0.000 \\
\hline 16 & -1.088 & 0.290 & 3.876 & 0.000 \\
\hline 17 & -0.710 & -0.269 & 3.072 & 0.000 \\
\hline 18 & -0.173 & -1.037 & 2.773 & 0.000 \\
\hline 19 & -0.556 & -0.410 & 3.005 & 0.000 \\
\hline 20 & -0.613 & -0.520 & 2.853 & 0.000 \\
\hline 21 & 0.759 & -0.646 & 3.614 & 0.000 \\
\hline 22 & -0.455 & -0.615 & 3.457 & 0.000 \\
\hline 23 & -0.648 & -0.471 & 3.283 & 0.000 \\
\hline 24 & -1.073 & 0.140 & 3.743 & 0.000 \\
\hline 25 & 0.967 & 0.140 & 4.147 & 0.000 \\
\hline 26 & -0.037 & -0.861 & 2.713 & 0.000 \\
\hline 27 & -0.068 & -0.971 & 2.491 & 0.000 \\
\hline 28 & -0.356 & -0.474 & 3.531 & 0.000 \\
\hline 29 & 0.810 & -0.448 & 3.427 & 0.000 \\
\hline
\end{tabular}

Note: $\mathrm{Z}=$ Kolmogorov-Smirnov Z-statistic; $p=$ bilateral significance test.

Regarding the analysis of kurtosis, the indices are negative except for Items 1, 2, 3, 6, 7, 8, 11, $14,16,24$, and 25 . This showed that the scores are more grouped and located above the normal distribution curve.

Exploratory analysis is a factorial analysis that measures construct validity within an instrument or scale using the principal components method with varimax rotation. Exploratory factor analysis was carried out using a Kaiser-Meyer-Olkin index calculation extraction method and the Bartlett sphericity test $(\mathrm{KMO}=0.900 ; 2$ was 3045.648 for 406 degrees of freedom, significant at 0.000$)$. The result of this initial analysis suggested that six values explained $68.051 \%$ of the total variance.

The following table (Table 3) shows the results obtained in the component transformation matrix. The data in the table represent the factorial weights of the components; as defined by Comrey [73], if the value is below 0.3 , then the variables have less than $10 \%$ of their variance in common with the factor, and if it is above 0.3 [73], they have a factorial weight in the component. 
Table 3. Component transformation matrix.

\begin{tabular}{lcccccc}
\hline & Factor 1 & Factor 2 & Factor 3 & Factor 4 & Factor 5 & Factor 6 \\
\hline Factor 1 & 0.512 & 0.478 & 0.445 & 0.473 & 0.157 & 0.251 \\
Factor 2 & -0.596 & 0.431 & 0.338 & -0.173 & 0.522 & -0.206 \\
Factor 3 & 0.271 & -0.146 & -0.515 & 0.195 & 0.749 & -0.199 \\
Factor 4 & 0.176 & -0.493 & 0.420 & -0.452 & 0.368 & 0.458 \\
Factor 5 & -0.026 & -0.514 & 0.486 & 0.403 & -0.016 & -0.580 \\
Factor 6 & 0.527 & 0.238 & 0.099 & -0.585 & -0.072 & -0.556 \\
\hline
\end{tabular}

Note: Factor $1=$ Knowledge of teachers of computer programs and their use in the teaching practice; Factor 2 = Repercussions that information and communication technologies (ICTs) have on the teaching process; Factor 3 = Result obtained with ICT according to the learning style; Factor $4=$ Use of ICTs in their personal environment; Factor $5=$ Teachers' knowledge of the Smart City concepts and whether they are aware of its uses in the e-learning environment; Factor $6=$ Knowledge and use of video and audio editing programs.

The first factor (knowledge of teachers of computer programs and their use in the teaching practice) is related to the knowledge of computer programs and their use in the teaching practice of teachers; the results indicated that it made up $39.022 \%$ of the total variance, including items such as I1-knowledge of basic programs; I2-knowledge of personal interaction programs; I3-knowledge of blogs, chats, or forums; I7-use of basic programs; I8-use of personal interaction programs; and I9-use of blogs, chats, or forums.

The second factor (repercussions that ICTs have on the teaching process) related to the use of ICTs in the respondents' personal spheres, with the aim of finding out whether they use them to search for educational and sustainability activities and sports and cultural events in their city, and it covered $4.751 \%$ of the total variation. This included items such as I11—“I use online video portals", I12-“I use ICTs to share resources about educational and sustainability activities and sports and cultural events", I13-“I expand academic information", and I14- "I look for information on academic and sustainability activities and sports and cultural events in my city".

The third factor (result obtained with ICTs according to the learning style) described the impact that ICTs have on the teaching process, and the results show that it made up $9.623 \%$ of the total variance, including items such as I16- "they help my teaching process", I17-“"they improve the academic results of my students", I18-"they replace traditional resources", I19-“"they encourage e-learning use", and I20- "it means that online teaching is more dynamic and time-efficient".

The fourth factor (use of ICTs in their personal environment) related to the results obtained with ICTs according to the learning style, and results indicated that this comprised $6.682 \%$ of the total variance, including items such as I23-“I enjoy preparing my lessons using ICTs", I24-“I use ICTs to achieve effectiveness in my teaching practice", I26-" "before working with ICTs, I analyze their pros and cons", I27- “I find out what other teachers think through communication platforms", and I28-“I try to reach conclusions about my work using ICTs".

The fifth factor (teachers' knowledge of the Smart City concept and whether they are aware of its uses in the e-learning environment) focused on whether teachers knew about the concept of Smart Cities and whether they were aware of their uses in the educational field; this factor accounted for $4.183 \%$ of the total variation, and included elements such as I21- "the Smart City is a valuable tool for acquiring academic knowledge, sustainability activities, and sports and cultural events", I25- "I am overwhelmed by the challenge of using ICTs", and I29-" "a Smart City project would have a positive impact on the academic performance of students".

The sixth factor (knowledge and use of video and audio editing programs) related to teachers' knowledge and use of video and audio editing programs, accounting for $3.790 \%$ of the total variance and including items such as I4- "I know of video and audio editing programs" and I10— "I use video and audio editing programs".

An analysis based on the structural equation model or a structural analysis of covariance that falls within confirmatory factor analysis can be used to analyze the relationships between a set of observed variables and a latent variable [63]. Via the analysis of the structural equation model according 
to the criterion of multivariate normality of the items and by the criterion of maximum likelihood, the questionnaire was perfected, which is why two models were made: a confirmatory model and a readjustment that modified the theoretical model (M1) by improving the variation of the estimated parameters and residual values. The modification was tested through adjustment indexes [63,72-76].

- Model (M1). This model arose from the exploratory factor analysis and served as a theoretical model. The parsimony normed fit index (PNFI) was close to 1 (0.750), and the CFI (comparative index of goodness of fit), TLI (Tucker-Lewis index), and NFI (normed fit index) comparative fit indices were $0.906,0.920$, and 0.901 , respectively. Although they all showed good results, it was necessary to study others. It is worth highlighting that the root mean approximation square error (RMSEA) was slightly above the critical limit at 0.059 [62,63,75,77-80].

- $\quad$ Model (M2). This model was created from the first model (Figure 2) by eliminating inappropriate items [76]. It retained 21 of the 24 items and four of the five factors of Model 1: knowledge of computer programs and their use in the teaching practice of teachers, impacts that ICTs have on the teaching process during their professional activity, results that are obtained from ICTs according to the style of learning, and use of ICTs in their personal environment. It was interesting to note that the calculated RMSEA, which was equal to 0.46, was an optimal value, and the CFI, TLI, and NFI comparative fit indices were 0.951, 0.961, and 0.952, respectively (Table 4 and Figure 3) $[62,63,75,77-80]$.

Table 4. The model (M1-M2) comparison for the SCOLQ.

\begin{tabular}{cccccccccc}
\hline & & \multicolumn{9}{c}{ Absolute Adjustment Index } & \multicolumn{3}{c}{ Increased Adjustment Index } \\
\hline Model & CMIN & P & LO 90 & HI 90 & RMSEA & PNFI & NFI & CFI & TLI \\
\hline $\begin{array}{c}\text { M1 } \\
\text { F Factors }\end{array}$ & 815.4 & 0.000 & 0.49 & 0.69 & 0.059 & 0.750 & 0.906 & 0.920 & 0.901 \\
$\begin{array}{c}24 \text { items } \\
\text { M2 }\end{array}$ & & & & & & & & & \\
$\begin{array}{c}\text { 4 Factors } \\
\text { 21 items }\end{array}$ & 684.1 & 0.000 & 0.39 & 0.58 & 0.046 & 0.789 & 0.951 & 0.961 & 0.952 \\
\hline
\end{tabular}

The analysis revealed satisfactory results for validity and reliability. The reliability obtained with Cronbach's alpha was 0.938 . The estimation of the reliability in terms of the scale scores was carried out by ordinal alpha [81].

The structural equation model (SEM) was constructed using multivariate regression statistical analysis in PANTH GRAHF. The values indicated a unidirectional influence between the observed and latent variables. Among the goodness-of-adjustment values, the root mean approximation square error (RMSEA) was 0.046 [63], and the lower and upper limits $(0.039 ; 0.048)$ at a confidence level of $90 \%$ formed an appropriate range; the normalized fit index (NFI [75]) was 0.951; and the comparison with respect to the saturated model (CFI [62]) was 0.961 . These values were more than adequate, indicating that the measurement model and data fit well; therefore, the construct validity was verified. The value of the model had 274 degrees of freedom with a maximum probability, a $\chi 2$ de of 815.459 , and a $p$ below 0.05 ; three variables were eliminated from the 24 , and the factors were reduced from five to four for greater convergence of the model.

The results of the CFA confirm the readjustment of the data to the corrected model (M2), with CFI $=0.961$ and $\mathrm{RMSEA}=0.046(90 \% \mathrm{CI}=0.039 ; 0.058)$. The analysis of the CFA was carried out with the SEM methodology through a path graph (Figure 3). As shown in Figure 3, all the weights are more than 0.05 , and the covariance between factors varied between 0.20 and 0.92 . The SEM evaluation verified that the derived coefficients showed a positive direction with the theory used to shape the measurement model, although one value was not well connected. The regression coefficients between 
latent and observed variables were mainly positive and varied between 0.45 and 1.00 , as shown in Table 2.

\section{Discussion}

An ICT exploratory analysis was performed on the data obtained from the sample. The Kaiser-Meyer-Olkin (KMO) index, the value of which must be over 0.50, was 0.900, a coefficient close to 1 , thus indicating that it was appropriate to proceed with the validity and reliability study. The Bartlett sphericity test proved that the significance was adequate $(p<0.001)$, showing that the data matrix was adequate for factorization. Analysis using the main-component-extraction method revealed a recommended number of six factors. However, accounting for the factor weighting once the matrix and the content of each question were broken down into component items, a five-factor extraction was considered to be more appropriate, in that the construct was much better represented from a theoretical perspective and more aligned with the objective that the questionnaire was attempting to measure. Exploratory factor analysis of the main components also identified a six-factor structure accounting for $68.051 \%$ of the variance, but for reasons of fit, as previously explained, five factors were used for greater convergence.

The results of the validation confirmed the theoretical structure of the questionnaire, but also revealed deviations in Items 8 and 13, thus suggesting that corrections should be made to improve the validity of the tool. These results were accepted by way of an empirical correction of the originally postulated theoretical structure and an additional confirmation (readjustment M2). The item considered to have negative variance required attention, with suggested elimination of said variable. The influence that the latent variable exerted on the observed variables showed that when the former increased by 1, the latter increased proportionately. The multivariable regression coefficient analysis was carried out by covariance matrix analysis of the observed variables, which was carried out using the LISREL v9.1. program.

Dawes and Pardo [21] established three categories of Smart City components. These categories are people, institutions, and technology. A Smart City is one in which investments in these fields promote sustainable development and a better quality of life.

The Smart City ideal aims to create an environment in which everything revolves around the citizen, that is, to develop a system with a citizenry that acts as a backbone [82]. The use of Smart Cities should allow communication between users and provide for the exchange of information.

Technical and technological transformations are manifested in progressive computerization, a situation in which people have been immersed accidentally and without warning during the crisis caused by the SARS-CoV-19 virus. This emergency has led to the urgent need to update the infrastructure required for the modification of educational aspects, such as the creation of professional profiles, the restructuring of educational curricula, the increase in new methodological approaches in the teaching-learning process, and the transformation of the professional profiles of teachers through the use of new technologies in the educational process [83]. The effects generated by this pandemic in an increasingly changing world mean that the efforts made in the field of education can be applied in different ways [84].

To this end, our questionnaire on the use of Smart City participation as a knowledge tool in the COVID-19 (Appendix A) is useful, valid, and reliable for analyzing the use of ICTs in education, and its links to the Smart City concept show great stability and good internal strength based on component covariance analysis in the challenge of online learning.

The use of new technologies requires that teachers have knowledge, skills, and attitudes that empower them to take advantage of and apply information and communication technologies in the educational process. By incorporating them, students can achieve important competencies [85]. Therefore, the developed questionnaire met the need to study the situation of teachers and the actions to be implemented in terms of expanding the sources of information collected in our section of smart education [64], thus increasing individual and collaborative learning experiences of learning without 
barriers of space and time, as framed in our dimension of the impact that ICTs have on the teaching process [65]. Middleton [66] relates increased interaction in the learning process and promotion of autonomy in learning, an essential factor that is also included in our smart learning environment dimension [68], as well as increasing motivation and responsibility during learning, which are included in the last section of our questionnaire [83].

In short, given that there were no tests with subsequent samples related to the validity of the tool, our conclusions focus on the results reported herein.

We therefore recommend the use of this tool in similar conditions to those employed for its validation $[60,86]$. With respect to the limitations of the present research, it should be underlined that the study offers only an initial analysis of the validity of the questionnaire, and the results should be treated with due caution, since further research will either verify or disprove the validity while enabling recommendations for improvement and changes in the theoretical premises.

\section{Conclusions}

We conclude that the results of the CFA were obtained through the SEM method using a path diagram to confirm the readjustment of the data to the corrected model (M2). It is observed that all the weights of the derived coefficients show a positive relationship with the proposed dimensions (Smart Education, Smart Learning Environment, impact that ICTs have on the teaching process, and the use of the Smart City and its usefulness in the e-learning), since when the latent variable increases, a unit, the observed variable, also increases according to the weight of the coefficient. Therefore, respondents have an adequate perception of the knowledge and use of basic programs, personal interaction programs, blogs, chats, or forums, and online video portals in relation to the Smart Education dimension. This also occurs with the Smart Learning Environment dimension, where the subjects evaluated consider that they make good use of online video portals. ICTs to share educational and sustainability activities, sports and cultural events, and academic information are also considered with respect to the third factor, the impact that ICTs have on the teaching process, to have a positive effect on such process, to improve the quality of learning and results of their students, and to enhance more dynamic and time-efficient teaching practices. In the last part of the questionnaire, teachers report a positive perception regarding the preparation of their lessons using ICTs, which they regard as very pleasant and effective and with more pros than cons, and they state that they will continue to use ICTs in their work, all this within the dimension of use of the Smart City and its usefulness in e-learning.

Our research succeeded in developing a useful instrument for evaluation in the form of a designed questionnaire, since the relationships between the latent and observed variables were positive, which established the consistency of its factor structure. The various indices used to establish the exact goodness of fit, such as the RMSEA, CFI and NFI, showed favorable results. The results of the SEM model allowed us to conclude that the model's estimate is good, since it demonstrated the validity of the construct of the Smart City questionnaire, promoting the constant improvement of information and communication technologies, their more frequent use, and their adaptation to the demands of society so that these technologies can provide an excellent environment for the dissemination of information [87-89].

In future lines of research, we aim to analyze the impact that online learning is having on students, whether the use of this tool is sustainable, and how online knowledge influences social relations, namely, the new socialization in Smart Cities.

Author Contributions: M.d.C.O.-G., M.L.-S., and S.M.-M., conceptualization; M.d.C.O.-G., methodology and validation; S.M.-M., analysis of the data; M.d.C.O.-G. and M.L.-S., writing-review and editing; M.d.C.O.-G., supervision. All authors contributed to data interpretation of the analysis. M.d.C.O.-G., M.L.-S., and J.M.C.-R. wrote the paper with significant input from M.d.C.O.-G. All authors have read and agreed to the published version of the manuscript. 
Funding: This research received external funding from Project HUM-983 (ITACA): "Research through transforming learning and contexts". Principal Researcher: Eva María Olmedo-Moreno.

Conflicts of Interest: The authors declare no conflict of interest.

\section{Appendix A. Questionnaire on the Knowledge and Use of the Smart City and Its Usefulness in Online Learning (SCOLQ)}

1. Sex: __ Female/__ Male

2. Educational level you teach:

\begin{tabular}{c}
\hline Primary education \\
\hline Secondary education \\
\hline University \\
Other \\
\hline
\end{tabular}

\begin{tabular}{|c|c|c|c|c|}
\hline Smart Education & NONE & SOME & QUITE A BIT & A LOT \\
\hline \multicolumn{5}{|l|}{ I1/I have knowledge of basic programs. } \\
\hline \multicolumn{5}{|l|}{ I2/I have knowledge of personal interaction programs. } \\
\hline \multicolumn{5}{|l|}{ I3/I have knowledge of blogs, chats, or forums. } \\
\hline \multicolumn{5}{|l|}{ I5/I know of and use online video portals. } \\
\hline \multicolumn{5}{|l|}{ I7/I use basic programs. } \\
\hline \multicolumn{5}{|l|}{ I8/I use personal interaction. } \\
\hline \multicolumn{5}{|l|}{ I9/I use blogs, chats, or forums. } \\
\hline \multicolumn{5}{|l|}{ Smart Learning Environment } \\
\hline \multicolumn{5}{|l|}{ I11/I use online video portals. } \\
\hline \multicolumn{5}{|l|}{$\begin{array}{l}\text { I12/I use ICTs to share resources about educational and } \\
\text { sustainability activities and sports and cultural events. }\end{array}$} \\
\hline \multicolumn{5}{|l|}{ I13/I expand academic information. } \\
\hline \multicolumn{5}{|l|}{$\begin{array}{l}\text { I14/I look for information about academic and sustainability } \\
\text { activities and sports and cultural events in my city }\end{array}$} \\
\hline \multicolumn{5}{|l|}{ Impact that ICTs have on the teaching process } \\
\hline \multicolumn{5}{|l|}{ I16/They help my teaching process. } \\
\hline \multicolumn{5}{|l|}{ I17/They improve the academic results of my students. } \\
\hline \multicolumn{5}{|l|}{ I18/They replace traditional resources. } \\
\hline \multicolumn{5}{|l|}{ I19/They encourage e-learning use. } \\
\hline \multicolumn{5}{|l|}{$\begin{array}{l}\text { I20/It means that online teaching is more dynamic and } \\
\text { time-efficient. }\end{array}$} \\
\hline \multicolumn{5}{|l|}{ Use of the Smart City and its usefulness in the e-learning } \\
\hline \multicolumn{5}{|l|}{ I23/I enjoy preparing my lessons using ICTs. } \\
\hline \multicolumn{5}{|l|}{ I24/I use ICTs to achieve effectiveness in my teaching practice. } \\
\hline \multicolumn{5}{|l|}{ I26/Before working with ICTs, I analyze their pros and cons. } \\
\hline \multicolumn{5}{|l|}{$\begin{array}{l}\text { I27/I find out what other teachers think through } \\
\text { communication platforms. }\end{array}$} \\
\hline I28/I try to reach conclusions about my work using ICTs. & & & & \\
\hline
\end{tabular}




\section{References}

1. Vieta, E.; Pérez, V.; Arango, C. La psiquiatría en las secuelas de COVID-19. Rev. Psiquiatr. Salud Mental 2020, 1-6. [CrossRef] [PubMed]

2. Sohrabi, C.; Alsafi, Z.; O’Neill, N.; Khan, M.; Kerwan, A.; Al-Jabir, A.; Agha, R. World Health Organization declares global emergency: A review of the 2019 novel coronavirus (COVID-19). Int. J. Surg. 2020, 76, 71-76. [CrossRef] [PubMed]

3. Olmos-Gómez, M.D.C. Sex and careers of university students in educational practices as factors of individual differences in learning environment and psychological factors during COVID-19. Int. J. Environ. Res. Public Health 2020, 17, 5036. [CrossRef] [PubMed]

4. AMETIC. Smartcities. Foro TIC Para La Sostenibilidad. 2012. Available online: http://ametic.es/sites/default/ files/Informe_Smart_Cities.pdf (accessed on 16 September 2020).

5. Fernández, J.M. Ciudades Inteligentes. La mitificación de las nuevas tecnologías como respuestas a los retos de las ciudades contemporáneas. Econ. Ind. 2015, 395, 17-28.

6. Bin, S.; Alamery, A.H.; Al Nafesa, A.; Aleid, B.; Brazanji, N.A. School closure during novel influenza: A systematic review. J. Infect. Public Health 2018, 11, 657-661. [CrossRef]

7. UNESCO. COVID-19 Impact on Education. Available online: https://www.iesalc.unesco.org/en/2020/03/09/ coronavirus-covid-19-and-higher-education-impact-and-recommendations/ (accessed on 16 August 2020).

8. Agrasso, M.; Jiménez, M.D.P. Percepción de los problemas ambientales por el alumnado: Los recursos naturales. Didác. Cienc. Experim. Soc. 2003, 17, 91-105.

9. Gutiérrez, J.; Calvo, S.; Benayas, J. Educación para el desarrollo sostenible: Evaluación de retos y oportunidades del decenio 2005-2014. Rev. Iberoam. Educ. 2006, 40, 25-69.

10. Bahner, D.; Adkins, E.; Patel, N.; Donley, C.; Nagel, R.; Kman, N. How we use social media to supplement a novel curriculum in medical education. Med. Teach. 2012, 34, 439-444. [CrossRef] [PubMed]

11. Blattner, G.; Fiori, M.; College, D. Virtual social network communities: An investigation of language learners' development of sociopragmatic awareness and multiliteracy skills. CALICO J. 2011, 29, 24-43. [CrossRef]

12. Churchill, D. Web 2.0 in education: A study of the explorative use of blogs with a postgraduate class. Innov. Educ. Teach. Int. 2011, 48, 149-158. [CrossRef]

13. Joubert, M.; Wishart, J. Participatory practices: Lessons learnt from two initiatives using online digital technologies to build knowledge. Comput. Educ. 2012, 59, 110-119. [CrossRef]

14. Manca, S.; Ranieri, M. Is Facebook still a suitable technology-enhanced learning environment? An updated critical review of the literature from 2012 to 2015. J. Comput. Assist. Learn. 2016, 32, 503-528. [CrossRef]

15. Price, D.; Lemoine, C.; South, N.; Hossain, R. First year nursing students use of social media within education: Results of a survey. Nurs. Educ. Today 2018, 61, 70-76. [CrossRef] [PubMed]

16. Sharma, S.K.; Joshi, A.; Sharma, H. A multi-analytical approach to predict the Facebook usage in higher education. Comput. Hum. Behav. 2016, 55, 340-353. [CrossRef]

17. Sun, Y.; Yang, F. I help, therefore, I learn: Service learning on web 2.0 in an EFL speaking class. Comput. Assist. Lang. Learn 2015, 28, 202-219. [CrossRef]

18. Paskaleva, K.A. The smart city: A nexus for open innovation? Intell. Build. Int. 2011, 3, 153-171. [CrossRef]

19. Hollands, R.G. Will the real smart city please and stand up? City 2008, 12, 303-320. [CrossRef]

20. Allwinkle, S.; Cruickshank, P. Creating smarter cities: An overwiew. J. Urban Technol. 2011, 18, 1-16. [CrossRef]

21. Dawes, S.S.; Pardo, T.A. Building collaborativa digital government systems. In Advances in Digital Government. Advances in Database Systems; McIver, W.J., Elmagarmid, A.K., Eds.; Springer: Boston, MA, USA, 2002; Volume 26. [CrossRef]

22. Partridge, H.L. Developing a Human Perspective to the Digital Divide in the Smart City. In Proceedings of the Austrialian library and Information Association Biennial Conference, Gold Coast, QLD, Australia, 21-24 September 2004.

23. Harrison, C.; Eckman, B.; Hamilton, R.; Hartswick, P.; Kalagnanam, J.; Paraszczak, J.; Williams, P. Foundations for smarter cities. IBM J. Res. Dev. 2010, 54, 1-16. [CrossRef]

24. Giffinger, R.; Fertner, C.; Kramar, H.; Meijers, E. Ranking of European Medium-Sized Cities; Vienna University of Technology: Vienna, Austria, 2007. 
25. Shapiro, J.M. Smart Cities: Explaining the Relationship between City Growth and Human Capital; Harvard University: Cambridge, MA, USA, 2003.

26. Caragliu, A.; Del Bo, C.; Nijkamp, P. Smart Cities in Europe. J. Urban Technol. 2011, 18, 65-82. [CrossRef]

27. Klein, C.; Kaefer, G. From smart homes to smart cities: Opportunities and challenges from an industrial perspective. In Next Generation Teletraffic and Wired/Wireless Advanced Networking. NEW2AN 2008; Balandin, S., Moltchanov, D., Koucheryavy, Y., Eds.; Lecture Notes in Computer Science; Springer: Berlin/Heidelberg, Germany, 2008; Volume 5174.

28. Aguaded, E. Smart city and Intercultural Education. Soc. Behav. Sci. 2017, 237, 326-333. [CrossRef]

29. Parlamento Europeo. Mapping Smart Cities in the EU. Available online: https://www.europarl.europa.eu/ RegData/etudes/etudes/join/2014/507480/IPOL-ITRE_ET(2014)507480_EN.pdf (accessed on 16 July 2020).

30. Lanza, J.; Santana, J.R.; Sánchez, L.; Muñoz, L.; Galache, J.A.; Sotres, P.; Gutiérrez, V. Large-scale mobile sensing enabled Internet-of-Things testbed for smart city services. Int. J. Distrib. Sens. Netw. 2015, 1-15. [CrossRef]

31. Sánchez, E.M. Hacia la smart city. Rev. Dig. CEMCI 2016, 32, 1-23.

32. Carrasco-Sáez, J.L.; Careaga Butter, M.; Badilla-Quintana, M.G. The new pyramid of needs for the digital citizen: A transition towards smart human cities. Sustainability 2017, 9, 2258. [CrossRef]

33. COVID; Team CDC; Response Team. Severe outcomes among patients with coronavirus disease 2019 (COVID-19)—United States, February 12-March 16, 2020. MMWR Morb. Mortal. Wkly. Rep. 2020, 69, 343-346. [CrossRef] [PubMed]

34. Burbules, N. El aprendizaje ubicuo y el futuro de la enseñanza. Encount. Educ. 2012, 13, 3-14. [CrossRef]

35. Lan, Y.J.; Sung, Y.T.; Chang, K.E. A mobile-device-supported peer-assisted learning system for collaborative early EFL reading. Lang. Learn. Technol. 2007, 11, 130-151.

36. Roschelle, J.; Rafanan, K.; Bhanot, R.; Estrella, G.; Penuel, B.; Nussbaum, M. Scaffolding group explanation and feedback with handheld technology: Impact on students mathematics learning. Educ. Technol. Res. Dev. 2010, 58, 399-419. [CrossRef]

37. Liu, T.C.; Lin, Y.C.; Tsai, M.J.; Paas, F. Split-attention and redundancy effects in mobile learning in physical environments. Comput. Educ. 2012, 58, 172-180. [CrossRef]

38. FUNDAC TELEFONICA. Smart cities: Un primer paso hacia el internet de las cosas. Fundación Telefónica. Editoral Ariel. Madrid. 2011. Available online: https://www.aeiciberseguridad.es/descargas/categoria6/ 9704170.pdf (accessed on 16 September 2020).

39. Suárez, M. De las smart cities a los smart citizens. La ciudadanía frente a la tecnología en la construcción de la resiliencia urbana. URBS. Rev. Est. Urbano Cienc. Soc. 2016, 6, 121-128.

40. Xue, S.; Churchill, D. A review of empirical studies of affordances and development of a framework for educational adoption of mobile social media. Educ. Technol Res. Dev. 2019, 67, 1231-1257. [CrossRef]

41. De Meo, P.; Messina, F.; Rosaci, D.; Sarné, G.M. Combining trust and skills evaluation to form e-Learning classes in online social networks. Inf. Sci. 2017, 405, 107-122. [CrossRef]

42. Mason, J.; Chen, W.; Hoel, T. Questions as data: Illuminating the potential of learning analytics through questioning an emergent field. RPTEL 2016, 11, 1-14. [CrossRef] [PubMed]

43. De Pablos-Pons, J.; Colás-Bravo, P.; González-Ramírez, T.; del Rey, C.C.M.V. Teacher well-being and innovation with information and communication technologies; proposal for a structural model. Qual. Quant. 2013, 47, 2755-2767. [CrossRef]

44. Flores, J.M. Nuevos modelos de comunicación, perfiles y tendencias en las redes Sociales. Rev. Cient. Iberoam. Comun. Educ. 2009, 33, 73-81. [CrossRef]

45. Sáiz-Manzanares, M.C.; Escolar-Llamazares, M.C.; Arnaiz González, Á. Effectiveness of blended learning in nursing education. Int. J. Environ. Res. Public Health 2020, 17, 1589. [CrossRef]

46. Khalifeh, G.; Noroozi, O.; Farrokhnia, M.; Talaee, E. Higher education students' perceived readiness for computer-supported collaborative learning. Multimodal Technol. Interact. 2020, 4, 11. [CrossRef]

47. Avello Martínez, R.; Duart, J.M. Nuevas tendencias de aprendizaje colaborativo en e-learning: Claves para su implementación efectiva. Est. Pedag. Valdivia 2016, 42, 271-282. [CrossRef]

48. Graf, S.; Liu, T.C.; Chen, N.S.; Yang, S.J. Learning styles and cognitive traits-Their relationship and its benefits in web-based educational systems. Comput. Hum. Behav. 2009, 25, 1280-1289. [CrossRef]

49. Alazab, M. Automated malware detection in mobile app stores based on robust feature generation. Electronics 2020, 9, 435. [CrossRef] 
50. Robbins, S.; Singer, J. The medium is the message: Integrating social media and social work education. J. Soc. Work. Educ. 2014, 50, 387-390. [CrossRef]

51. Tang, Y.; Hew, K.F. Is mobile instant messaging (MIM) useful in education? Examining its technological, pedagogical, and social afordances. Educ. Res. Rev. 2017, 21, 85-104. [CrossRef]

52. Lund, A.; Furberg, A.; Bakken, J.; Engelien, K.L. What does professional digital competence mean in teacher education? Nord. J. Dig. Liter. 2014, 9, 280-298.

53. García-Peñalvo, F.J.; Corell, A.; Abella-García, V.; Grande, M. La evaluación online en la educación superior en tiempos de la COVID-19. Educ. Knowl. Soc. 2020, 21, 1-26. [CrossRef]

54. Van Laar, E.; van Deursen, A.J.; van Dijk, J.A.; de Haan, J. The relation between 21st-century skills and digital skills: A systematic literature review. Comput. Hum. Behav. 2017, 72, 577-588. [CrossRef]

55. Hinostroza, J.E. TIC, Educación y Desarrollo Social en América Latina y el Caribe; UNESCO: Montevideo, Uruguay, 2017.

56. Goldschmidt, K. The COVID-19 pandemic: Technology use to support the wellbeing of children. J. Pediatric. Nurs. 2020, 53, 88-90. [CrossRef] [PubMed]

57. Rizopoulos, D. ltm: Un paquete R para el modelado de variables latentes y análisis de teoría de respuesta al ítem. Revi. Softw. Estad. 2006, 17, 1-25.

58. Olmedo, E.M.; Expósito, J. Entornos personales de aprendizaje en los jóvenes de las smart cities actuales y futuras. Rev. Iberoamer Icana Sist Cibern. Inform. 2017, 14, 1-5.

59. Díaz, M.R. Introducción a los modelos de ecuaciones estructurales. Publicaciones del INICO 2000, 43, 70-75. Available online: http://riberdis.cedd.net/bitstream/handle/11181/3270/Metodologia_en_investigacion_sobre_ discapacidad.pdf? sequence $=2 \#$ page $=44$ (accessed on 16 August 2020).

60. Olmedo, E.M.; Berrocal, E.; Olmos, M.C.; Expósito, J. Structural Equations Model (SEM) of a questionnaire on the evaluation of intercultural secondary education classrooms. Suma Psicol. 2014, 21, 107-115. [CrossRef]

61. Muñiz, J. Las teorías de los tests: Teoría clásica y teoría de respuesta a los ítems. Pap. Psicólogo 2010, 31, 57-66.

62. Bentler, P.M. On tests and indices for evaluating structural models. Personal. Individ. Differ. 2007, 42, 825-829. [CrossRef]

63. González, M.J.; Backhoff, E. Validación de un cuestionario de contexto para evaluar sistemas educativos con Modelos de Ecuaciones Estructurales. RELIEVE. Rev. Electron. Investig. Eval. Educ. 2010, 16, 1-17.

64. Zhu, Z.T.; He, B. Smart Education: New frontier of educational informatization. E-education Res. 2012, 12, $1-13$.

65. Hoel, T.; Mason, J. Standards for smart education-Towards a development framework. Smart Learn. Environ. 2018, 5, 3. [CrossRef]

66. Middleton, A. Smart Learning: Teaching and learning with Smartphones and Tablets in Post-Compulsory Education; MELSIG: Sheffield, UK, 2015.

67. Liu, D.; Huang, R.; Wosinski, M. Contexts of smart learning environments. In Smart Learning in Smart Cities; Springer: Singapore, 2017; pp. 15-29.

68. Kim, S.; Song, S.M.; Yoon, Y.I. Smart learning services based on smart cloud computing. Sensors 2011, 11, 7835-7850. [CrossRef] [PubMed]

69. Roumen, E.S.; Kovatcheva, N.E. Conceptualising of Smart Education. 2018. Available online: https://www.researchgate.net/publication/320623528_Conceptualising_of_Smart_Education (accessed on 16 September 2020).

70. Howell, D.; William, O.; Turner, S. The analysis of missing data. In Handbook Social Science Methodology; Sage: London, UK, 2008; pp. 208-224.

71. Escobar, J.; Cuervo, A. Validez de contenido y juicio de expertos: Una aproximación a su utilización. Avanc. Medic. 2008, 6, 27-36.

72. Cohen, J. Statistical Power Analysis for the Social Sciences; Erlbaum Associates: Hillsdale, NJ, USA, 1988.

73. Comrey, A.L. Manual de Análisis Factorial; Cátedra: Madrid, Spain, 1985.

74. Kline, R.B. Convergence of Structural Equation Modeling and Multilevel Modeling; Sage: Thousand Oaks, CA, USA, 2011.

75. Bentler, P.; Bonett, D. Significance tests and goodness of fit in the analysis of covariance structures. Psychol. Bull. 1980, 88, 588. [CrossRef] 
76. Batista-Foguet, J.M.; Coenders, G.; Alonso, J. Análisis factorial confirmatorio. Su utilidad en la validación de cuestionarios relacionados con la salud. Med. Clin. 2004, 122, 21-27. [CrossRef]

77. Jöreskog, K.G.; Sörbom, D. LISREL VI. Analysis of Linear Structural Relationships by Maximum Likelihood, Instrumental Variables, and Least Squares Methods; Scientific Software: Mooresville, IN, USA, 1984.

78. Hu, L.T.; Bentler, P.M. Cutoff criteria for fit indexes in covariance structure analysis: Conventional criteria versus new alternatives. Struct. Equ. Model. Multidiscip. J. 1999, 6, 1-55. [CrossRef]

79. Sivo, S.A.; Fan, X.; Witta, E.L.; Willse, J.T. The search for "optimal" cutoff properties: Fit index criteria in structural equation modeling. J. Exper. Educ. 2006, 74, 267-288. [CrossRef]

80. Miles, J.; Shevlin, M. A time and a place for incremental fit indices. Personal. Individ. Differ. 2007, 42, 869-874. [CrossRef]

81. Elosua, P.; Zumbo, B. Reliability coefficients for ordinal response scales. Psicothema 2008, 20, 896-901.

82. Enerlis, E.; Young, F. Libro Blanco Smart Cities. Madrid Network. Destinos Turísticos Inteligentes. SEGITTUR. España. Secretaría de Estado de Turismo. 2012. Available online: https://scholar.google.es/ scholar?q=Enerlis $\% 2 C+$ Ernst+and + Young $\% 2 C+$ Ferrovial $\% 2 C+$ Madrid + Network+\%282012\%29.\&btnG= \&hl=es\&as_sdt $=0 \% 2 \mathrm{C} 5$ (accessed on 17 September 2020).

83. Markovic, M.; Petrovic, Z.S. Changes in the school system-New media and learning. In The International Scientific Conference eLearning and Software for Education; Carol I National Defence University: Bucharest, Romania, 2017; pp. 160-166. [CrossRef]

84. Moorhouse, B.L. Adaptations to a face-to-face initial teacher education course 'forced' online due to the COVID-19 pandemic. J. Educ. Teach. 2020,1-3. [CrossRef]

85. Sedláková, S. One of the ways to reduce the cost of waste management municipality. Adm. Manag. Public. 2016, 26, 49-59.

86. Olmos, M.C.; Luque, M.; Ferrara, C.; Olmedo, E.M. Quality of higher education through the pursuit of satisfaction with a focus on sustainability. Sustainability 2020, 12, 2366. [CrossRef]

87. Androniceanu, A.; Drăgulănescu, I.V. Sustainability of the organizational changes in the context of global economic crisis. Amfiteatru Econ. J. 2012, 14, 365-379.

88. Kidman, G.; Chang, C. What does "crisis" education look like? Intern. Res. Geogr. Environ. Educ. 2020, 29, 107-111. [CrossRef]

89. Gewin, V. Five tips for moving teaching online as COVID-19 takes hold. Nature 2020, 580, 295-296. [CrossRef] 